\title{
Occupational exposure to noise and hypertension in pilots
}

\author{
FRANCESCO TOMEI ${ }^{1}$, SIMONE DE SIO ${ }^{1}$, ENRICO TOMAO $^{2}$, VINCENZA \\ ANZELMO $^{3}$, TIZIANA PAOLA BACCOLO ${ }^{1}$, MANUELA CIARROCCA ${ }^{1}$, \\ EMILIA CHERUBINI ${ }^{1}$, VALENTINA VALENTINI ${ }^{1}$, ASSUNTA \\ CAPOZZELLA $^{1}$, \& MARIA VALERIA ROSATI ${ }^{1}$
}

${ }^{1}$ University of Rome "La Sapienza", Department of Occupational Medicine, Rome, Italy, ${ }^{2}$ Center for Aeromedical Evaluation and Occupational Medicine IML, Rome, Italy, and ${ }^{3}$ Department of Occupational Medicine, Rome, Italy

\begin{abstract}
The role of occupational exposure to noise as a hypertension risk factor has not been established sufficiently. The aim of the study is to evaluate whether chronic exposure to different levels of noise in two groups of pilots, operating with two types of aircraft, could be a risk for hypertension, what relevance the parameters (intensity, duration and type) of exposure can have and, lastly, whether there are any links between hearing impairment and hypertension. After excluding pilots with confounding factors, a study was made of 77 male pilots of turboprop planes (group A) and 224 male pilots of jet aircraft (group B), matched by age and working life. Blood pressure (supine and standing positions) and heart rate were measured. Electrocardiogram, stress tests on a cycle ergometer, sound-level measurement and audiometric tests were also done. Pilots of group A were exposed to Leq of $93 \mathrm{dBA}$ while pilots of group B were exposed to the Leq of $79 \mathrm{dBA}$. Significant results in group A compared to group B were found between heart rate, blood pressure, drop in blood pressure, parameters (intensity, duration and type) of exposure to noise and between hearing damage and hypertension. The findings suggest that chronic exposure to noise is a risk factor for blood hypertension in pilots exposed to high noise levels, and that the drop in blood pressure may be a sign of more sensitive effect of noise on blood pressure, according to other studies in literature.
\end{abstract}

Keywords: Noise, hypertension, pilots, blood pressure, heart rate

\section{Introduction}

It is well known that noise can seriously damage the hearing system but it is only recently that research has been done on its possible contribution to hypertension (Van Kempen et al. 2002) and cardiovascular disease (Tomei et al. 1991; Kawada \& Suzuki 1999). It can be suggested that noise influences vascular tone, through direct and/or mediated mechanisms. The nonauditory effects of noise can manifest themselves through a series of nerve circuits represented, in addition to the reticular substance, by the limbic system, amygdala, 
hippocampus, hypothalamus and cortical nerve centres, also by autonomous nervous system (Bao et al. 1999).

Data on how noise affects different cardiovascular parameters are still conflicting, the different results may be linked to measurements taken at different stages of noise exposure (Tomei et al. 1992; Sokas et al. 1995; Marciniak et al. 1999). Sokas et al. (1995) investigated a possible relationship between noise-induced hearing loss and high blood pressure (BP). Other investigations are still being made to see whether there are any links between hearing impairment, hypertension and cardiovascular disease (Tomei et al. 2000).

The aim of the study is to evaluate whether chronic exposure to different levels of noise in two groups of pilots operating two types of aircraft, could be a risk for hypertension, what relevance the parameters (intensity, duration and type) of exposure can have and, lastly, whether there are any links between hearing impairment and hypertension.

\section{Methods}

Four hundred-and-sixteen male pilots comprised of 105 pilots of turboprop planes G222 and C130 (group A) and 311 pilots of jet planes F104 and G91 (group B) were randomly extracted from two populations ( $n=1471$, in total) of aircraft military pilots. Both samples of 105 and 311 pilots correspond to $28.1 \%$ of each category of pilots. Pilots in both groups were identified and classified in relation to the type of aircraft almost exclusively used (same type of aircraft $>90 \%$ ).

Excluded from the study were pilots of both types of aircraft, who were aged less than 24 years, who had a working life less than two years, a family history of cardiovascular disease and exposure to audiological risk factors outside work (noise trauma, bomb, mine or other explosions, use of firearms, previous otitis, severe head trauma, use of ototoxic drugs). Also excluded were all pilots with serum total cholesterol $>200 \mathrm{mg} / \mathrm{dl}$, blood glucose $>110 \mathrm{mg} /$ $\mathrm{dl}$, body mass index (BMI $\mathrm{Kg} / \mathrm{m}^{2}$ ) more than 30 and smoking habits (past and/or present smoking habit). As far as alcohol consumption was concerned, all the subjects included in the study were teetotallers or had negligible alcohol consumption (no spirits and less than 1 glass of wine or beer once a day or less).

Therefore, 115 workers were excluded from the study (mean age 41.9, SD 7.0 years, range 25 - 59 years; mean working life 21.9 , SD 6.8 years, range $2-40$ years). Thus, 301 pilots were studied: 77 in group A (turboprop pilots) and 224 in group B (jet pilots) matched by age and working life (by mean, SD and distribution; see Table I). Both populations of pilots perform analogous shift work. The flight hours from the start of the pilot's working life were calculated by means of a questionnaire and a check on the personal flight booklet. The pilots were further broken down into two sub-groups of pilots with flight hours of $<3000$ and $\geqslant 3000$, because 3000 hours was approximately the mean flight hours in both groups (see Table I). An International Electrotechnical Commission (IEC) 804 Class 1 noise meter-integrator (Amplifon Amplaid 309, Italy) was used to measure the equivalent continuous noise level (Leq), i.e., (the mean intensity of a variable noise, integrated over time, for the various working stages, expressed in decibels A (dBA), and computed the noise-frequency distribution). The measurements were taken in the cockpit with a phonometer situated at the level of the pilot's ear, inside the protecting flight helmet. All the subjects, after at least 16 hours not exposed to noise, underwent a liminal tonal audiometric examination for air and bone conduction, in a range of frequencies from 125 to $8000 \mathrm{~Hz}$. The audiometric curves for each ear were classified according to Klockoff, as modified by Merluzzi et al. 1987. Audiometry was done in accordance with International Standards Organization (ISO) rules 6189 - 1983, against normal room background noise, so as to measure an audible threshold of 
Table I. Characteristics of the population studied.

\begin{tabular}{|c|c|c|c|c|}
\hline \multirow{4}{*}{$\begin{array}{l}\text { Parameters } \\
\text { Age (yr) } \\
\text { mean }(\mathrm{SD}) \\
\text { range }\end{array}$} & \multicolumn{2}{|c|}{$\begin{array}{c}\text { Group A } \\
\text { (turboprop planes pilots) } \\
n=77\end{array}$} & \multicolumn{2}{|c|}{$\begin{array}{c}\text { Group B } \\
\text { (jet planes pilots) } \\
n=224\end{array}$} \\
\hline & \multirow{3}{*}{\multicolumn{2}{|c|}{$\begin{array}{c}40.5(8.0)^{\star} \\
25-57\end{array}$}} & & \\
\hline & & & \multicolumn{2}{|c|}{$39.0(8.0)$} \\
\hline & & & & \\
\hline \multicolumn{5}{|c|}{ Working life (yr) } \\
\hline mean (SD) & \multicolumn{2}{|c|}{$20.6(7.8)^{\star}$} & \multicolumn{2}{|c|}{$19.6(8.5)$} \\
\hline range & \multicolumn{2}{|c|}{$4-36$} & \multicolumn{2}{|c|}{$4-38$} \\
\hline \multicolumn{5}{|l|}{ Flight hours } \\
\hline mean (SD) & \multicolumn{2}{|c|}{$3285.7(1665.6)^{\star}$} & \multicolumn{2}{|c|}{$2851.9(1769.6)$} \\
\hline \multirow[t]{3}{*}{ range } & \multicolumn{2}{|c|}{$800-10040$} & \multicolumn{2}{|c|}{$750-10600$} \\
\hline & $<3000$ & $\geqslant 3000$ & $<3000$ & $\geqslant 3000$ \\
\hline & $n=29$ & $n=48$ & $n=141$ & $n=83$ \\
\hline \multicolumn{5}{|l|}{ Flight hours } \\
\hline mean & 1950.0 & 4395.5 & 1849.6 & 4554.8 \\
\hline$(\mathrm{SD})$ & $(607.1)$ & (1554.8) & (865.3) & (1762.7) \\
\hline range & $800-2900$ & $3000-10040$ & $800-2900$ & $3000-10600$ \\
\hline
\end{tabular}

${ }^{\star}$ not significant with respect to group B.

$0 \mathrm{~dB}$, in accordance with ISO $389-1979$. Audiometric findings for workers exposed to noise were compared with those for the general population, not exposed to noise, and not suffering from otological disease as specified in ISO 1999-1990. The correlation between flight hours and degree of hearing loss was also assessed. The workers fasted for at least 10 hours, and rested for at least $15 \mathrm{~min}$ in a room at a comfortable temperature, before the recording of heart rate (HR), BP, and electrocardiogram (ECG). All the workers were asked not to take any anti-hypertension medication for 12 hours before the test.

$\mathrm{BP}$ was measured in the morning after $5 \mathrm{~min}$ lying down, again $3 \mathrm{~min}$ later, and a third time after another $3 \mathrm{~min}$, with the subjects still lying down, and to study any postural change $30 \mathrm{sec}$ after they stood up according to World Health Organization guidelines (WHO 1999). The mean of the first three measurements was considered the mean BP and used to calculate the percentage of basal hypertensives (BH), using the WHO classification (WHO 1999). Lastly, the cases with a drop in systo-diastolic pressure while standing up (drop in BP) were taken into consideration. The cut-off point used for detecting the drop in systolic-diastolic blood pressure was $5 \mathrm{mmHg}$.

At resting $\mathrm{HR} \geqslant 84$ beats/min is predictive of an increase in cardiovascular mortality (Petiot et al. 1992). The percentage of subjects with at rest $H R \geqslant 84$ beats $/ \mathrm{min}$ was calculated. The stress test on the cycle ergometer was done immediately afterwards, in a seated position, increasing intensity of the stress by $30 \mathrm{~W}$ every $3 \mathrm{~min}$ with 50 revolutions a minute until the load that resulted in a HR of (200-age) was reached. The functional parameters, HR, BP and ECG were measured at each workload up to the maximum load and after 6 min of recovery.

All of the subjects consented to their personal details being available, declaring that they had been made aware that this data is ranked as "sensitive information", and consented that the data arising from the research protocol should be treated in an anonymous and collective way, with scientific methods and for scientific purposes in accordance with the principles of the Declaration of Helsinki.

Data were statistically analysed using frequencies, mean and standard deviation (SD) according to the nature of variables. Differences between means were assessed by Student's $t$ - 
test. Analyses of the variance were done to compare the means between the groups. Differences between frequency distributions were assessed by the chi-square test; Yate's correction for $2 \times 2$ contingency tables or the Fischer's exact test was used. The Pearson correlation coefficient $(r)$ was calculated. A $p$ value less than 0.05 was considered significant. Solo BMDP ${ }^{\circledR}$ statistical software was used for the statistical analyses.

\section{Results}

In group A, the equivalent continuous noise level (Leq) was $93 \mathrm{dBA}$, with peaks at takeoff and landing of $104 \mathrm{dBA}$. The noise-frequency distribution is unbalanced for low frequencies. In group B, Leq was $79 \mathrm{dBA}$ with similar characteristics related to frequencies. There was during taxiing an increase of $33 \mathrm{~dB}$ at $4000 \mathrm{~Hz}$ and up to $110 \mathrm{~dB}$ at $250 \mathrm{~Hz}$. Mean dyastolic blood pressure (DBP) and basal HR were significantly higher in group A than in group B (respectively $p=0.001$ and $p=0.001$ ) (see Table II).

There were significant differences between group A in respect to group B for the HR $\geqslant 84$ beats/min $(p=0.001)$, for the frequency of $\mathrm{BH}(p=0.001)$, for the drop in $\mathrm{BP}(p=0.005)$ and for the ECG anomalies $(p=0.001)$ (see Table II).

The prevalence of audiometric deficits was significantly higher in group A compared to group B $(p=0.002)$ (see Table II). The audiometric deficits due to noise exposure consisted of: Class II, $62 \%$ in group A and $63.2 \%$ in group B; class III, $6.9 \%$ and $10.3 \%$ respectively; class IV, $13.9 \%$ and $7.4 \%$ respectively; and class VI, $17.2 \%$ and $19 \%$ respectively.

The mean rise in the audiometric threshold in pilots of both groups was clearly higher than that expected in the general population of the same age not exposed to noise in ISO 1999 -

Table II. Heart rate (HR), systolic blood pressure (SBP), dyastolic blood pressure (DBP), HR $\geqslant 84$ beats $/ \mathrm{min}$, basal hypertension $(\mathrm{BH})$, drop in BP, ECG anomalies and audiometric deficits in two groups.

\begin{tabular}{|c|c|c|}
\hline Parameters & $\begin{array}{c}\text { Group A } \\
\text { (turboprop planes pilots) } \\
n=77\end{array}$ & $\begin{array}{c}\text { Group B } \\
\text { (jet planes pilots) } \\
n=224\end{array}$ \\
\hline \multicolumn{3}{|l|}{$\mathrm{HR} b / \min$} \\
\hline mean $(\mathrm{SD})$ & $87.9(10.1)$ * & $71.2(11.2)$ \\
\hline range & $56-102$ & $50-105$ \\
\hline \multicolumn{3}{|l|}{ SBP } \\
\hline mean $(\mathrm{SD})$ & $127.0(13.3)$ & $125.6(11.2)$ \\
\hline range & $100-165$ & $95-160$ \\
\hline \multicolumn{3}{|l|}{$\mathrm{DBP}$} \\
\hline mean $(\mathrm{SD})$ & $84.9(10.1)$ * & $78.8(9.4)$ \\
\hline range & $60-110$ & $60-115$ \\
\hline \multicolumn{3}{|l|}{$\mathrm{HR} \geqslant 84 \mathrm{~b} / \mathrm{min}$} \\
\hline No. cases (\%) & $30(38.9 \%) \star$ & $40(17.8 \%)$ \\
\hline \multicolumn{3}{|l|}{$\mathrm{BH}$} \\
\hline No. cases (\%) & $30(38.9 \%)$ * & $20(8.9 \%)$ \\
\hline \multicolumn{3}{|l|}{ Drop in $\mathrm{BP}$} \\
\hline No. cases (\%) & $47(61.0 \%) \star \star$ & $68(30.3 \%)$ \\
\hline \multicolumn{3}{|l|}{ ECG anomalies } \\
\hline No. cases $(\%)$ & $30(38.9 \%) \star$ & $35(15.6 \%)$ \\
\hline \multicolumn{3}{|l|}{ Audiometric deficits } \\
\hline No. cases (\%) & $30(38.9 \%) \#$ & $46(20.5 \%)^{\star}$ \\
\hline
\end{tabular}

${ }^{\star} p=0.001$ with respect to group $\mathrm{B} ;{ }^{\star \star} p=0.005$ with respect to group $\mathrm{B} ; \# p=0.002$ with respect to group $\mathrm{B}$. 
1990. Prevalence of $\mathrm{BH}$, drop in BP and ECG anomalies in relation to audiometric deficits are shown in Table III.

Strong correlations between flight hours and systolic blood pressure (SBP) and DBP were found in both group A (SBP, $r=0.97, p=0.003$; DBP, $r=0.98, p=0.003$ ) and group B (SBP, $r=0.86, p=0.025$; DBP, $r=0.76, p=0.005)$. No correlation was found between flight hours and ECG anomalies. A correlation was also found between flight hours and degree of hearing loss in both group $\mathrm{A}(r=0.88, p=0.02)$ and group $\mathrm{B}(r=0.87, p=0.02)$. The $\mathrm{BH}$, the drop in $\mathrm{BP}$, the ECG anomalies and the auditory deficits in relation to flight hours $(<3000$ flight hours and $>3000$ flight hours) are shown in Table IV.

The stress test on the cycle ergometer showed a greater systolic hypertensive response $(p=0.001)$ in the $\mathrm{BH}$ compared to the normotensives in both groups. The different SBP during stress between subjects with $\mathrm{BH}$ and normotensives was also maintained $(p=0.001)$ during the recovery phase. The maximal workloads reached were found to be in relation to age and working life. The subjects with a maximal load of up to $120 \mathrm{~W}$ mainly belonged $(p=0.001)$ to group A, while those with a maximal load of up to $210 \mathrm{~W}$ belonged to group B (no.6 $=1.9 \%)$.

In group A, a greater prevalence of ECG anomalies during ergometric test to the maximum load were found, compared to group B (group A $28.6 \%$, group B $8.9 \% ; p=0.001$ ), and to recovery (group A $25.9 \%$, group B $8.9 \%$; $p=0.001$ ).

In group $B$, the interruption at the various loads showed the same in pilots with and without drop in basal BP. In group A the subjects with interruption at $150 \mathrm{~W}$ were mainly those with drop in basal $\mathrm{BP}$, the ones at $180 \mathrm{~W}$ were mainly those without drop in basal $\mathrm{BP}$ $(p=0.045)$.

The HR increased in parallel to the BP, although the former tended to increase more. There were no significant differences in the HR during stress and on recovery, between the two groups of pilots. Some cases showed a low increase in HR at maximum stress (group A $2.8 \%$ and group B $2.2 \%$ ). In all cases, the reason for interruption of the test was muscular exhaustion $(7.6 \%$ in group $\mathrm{A}, 5.4 \%$ in group $\mathrm{B})$; there was no statistically significant

Table III. Prevalence of basal hypertension (BH), drop in BP and ECG anomalies in relation to audiometric deficits.

\begin{tabular}{|c|c|c|c|c|}
\hline & \multicolumn{2}{|c|}{$\begin{array}{c}\text { Group A } \\
\text { (turboprop planes pilots) } \\
n=77\end{array}$} & \multicolumn{2}{|c|}{$\begin{array}{c}\text { Group B } \\
\text { (jet planes pilots) } \\
n=224\end{array}$} \\
\hline & $\begin{array}{l}\text { With audiometric } \\
\begin{array}{l}\text { deficit } \\
n=30\end{array}\end{array}$ & $\begin{array}{l}\text { Without audiometric } \\
\qquad \begin{array}{l}\text { deficit } \\
n=47\end{array}\end{array}$ & $\begin{array}{l}\text { With audiometric } \\
\text { deficit } \\
n=46\end{array}$ & $\begin{array}{c}\text { Without audiometric } \\
\text { deficit } \\
n=178\end{array}$ \\
\hline \multicolumn{5}{|l|}{$\mathrm{HR} \geqslant 84 \mathrm{~b} / \mathrm{min}$} \\
\hline $\begin{array}{l}\text { No. cases }(\%) \\
\mathrm{BH}\end{array}$ & $21(70 \%)^{\star}$ & $9(19.1 \%)$ & $10(21.7 \%)^{\star \star}$ & $30(16.8 \%)$ \\
\hline $\begin{array}{l}\text { No. cases (\%) } \\
\text { Drop in BP }\end{array}$ & $24(80 \%)^{\star}$ & $6(12.7 \%)$ & $12(26.1 \%)$ & $8(4.5 \%)$ \\
\hline $\begin{array}{l}\text { No. cases }(\%) \\
\text { ECG anomalies }\end{array}$ & $24(80 \%) \#$ & $23(48.9 \%)$ & $23(50 \%)$ & $45(25.3 \%)$ \\
\hline No. cases $(\%)$ & $21(70 \%)^{\star}$ & $9(19.1 \%)$ & $8(17.4 \%)$ & $27(15.1 \%)$ \\
\hline
\end{tabular}

${ }^{\star} p=0.001$ with respect to pilots without audiometric deficit in the same group and pilots with audiometric deficit in group $\mathrm{B} ;{ }^{\star \star} p=0.001$ with respect to pilots without audiometric deficit in the same group; $\# p=0.013$ with respect to pilots without audiometric deficit in the same group and $p=0.017$ with audiometric deficit in group B. 
Table IV. The BH, the drop in BP, the ECG anomalies and auditory deficits in relation to the time of exposure in the two groups of pilots studied.

\begin{tabular}{|c|c|c|c|c|}
\hline & \multicolumn{2}{|c|}{$\begin{array}{c}\text { Group A } \\
\text { (turboprop planes pilots) } \\
n=77\end{array}$} & \multicolumn{2}{|c|}{$\begin{array}{c}\text { Group B } \\
\text { (jet planes pilots) } \\
n=224\end{array}$} \\
\hline & $\begin{array}{l}<3000 \\
n=29\end{array}$ & $\begin{array}{l}\geqslant 3000 \\
n=48\end{array}$ & $\begin{array}{l}<3000 \\
n=141\end{array}$ & $\begin{array}{l}\geqslant 3000 \\
n=83\end{array}$ \\
\hline \multicolumn{5}{|l|}{ Flight hours } \\
\hline mean $(\mathrm{SD})$ & $1950.0(607.1)$ & $4395.5(1554.8)$ & $1849.6(865.3)$ & $4554.8(1762.7)$ \\
\hline range & $800-2900$ & $3000-10040$ & $800-2900$ & $3000-10600$ \\
\hline \multicolumn{5}{|l|}{ Age } \\
\hline mean $(\mathrm{SD})$ & $35.6(9.1)$ & $43.4(5.6)^{\star}$ & $37.2(8.2)$ & $43.3(6.8)^{\star}$ \\
\hline range & $25-56$ & $34-55$ & $25-56$ & $35-56$ \\
\hline \multicolumn{5}{|l|}{ Working life } \\
\hline mean $(\mathrm{SD})$ & $15.9(8.9)$ & $23.4(5.6)^{\star}$ & $16.3(8.2)$ & $23.4(6.3)^{\star}$ \\
\hline range & $4-36$ & $16-34$ & $4-36$ & $15-32$ \\
\hline \multicolumn{5}{|l|}{$\mathrm{HR} \geqslant 84$} \\
\hline $\begin{array}{l}\text { No. cases (\%) } \\
\text { BH }\end{array}$ & \multicolumn{3}{|c|}{$\mathrm{BH}$} & $19(22.9 \%)$ \\
\hline $\begin{array}{l}\text { No. cases (\%) } \\
\text { Drop in BP }\end{array}$ & $2(7.0 \%)$ & $28(58.3 \%)^{\star \star \star}$ & $8(5.6 \%)$ & $12(14.4 \%) \#$ \\
\hline $\begin{array}{l}\text { No. cases (\%) } \\
\text { ECG anomalies }\end{array}$ & $10(34.4 \%)$ & $38(79.2 \%)^{\star \star \star}$ & $40(28.4 \%)$ & $28(33.7 \%)$ \\
\hline $\begin{array}{l}\text { No. cases (\%) } \\
\text { Hearing loss }\end{array}$ & $7(24.1 \%)$ & 23 (47.9 \%)\#\# & $21(14.8 \%)$ & $14(16.9 \%)$ \\
\hline No. cases (\%) & $6(20.1 \%)$ & $24(50.0 \%) \rrbracket$ & $26(18.4 \%)$ & $20(24.1 \%)$ \\
\hline
\end{tabular}

${ }^{\star} p=0.001$ with respect to pilots $<3000 \mathrm{~h}$ in the same group; ${ }^{\star \star} p=0.005$ with respect to pilots $<3000 \mathrm{~h}$ in the same group and $p=0.001$ with respect to pilots $\geqslant 3000 \mathrm{~h}$ in group $\mathrm{B} ;{ }^{\star \star \star} p=0.001$ with respect to pilots $<3000 \mathrm{~h}$ in the same group and to pilots $\geqslant 3000 \mathrm{~h}$ in group $\mathrm{B} ; \# p=0.049$ with respect to pilots $<3000 \mathrm{~h}$ in the same group; \#\# $p=0.001$ with respect to pilots $\geqslant 3000 \mathrm{~h}$ in group $\mathrm{B} ; \mathbb{\$} p=0.021$ with respect to pilots $<3000 \mathrm{~h}$ in the same group and $p=0.005$ with respect to pilots $\geqslant 3000 \mathrm{~h}$ in group $\mathrm{B}$.

difference between the two groups. No significant differences were found in prevalence of $\mathrm{BH}$ and basic ECG anomalies, age and working life between the two groups of pilots that interrupted the test.

\section{Discussion}

Considering that the principal confounding factors were excluded from the study and that pilots investigated were matched by age and working life, the above mentioned results suggest that exposure to noise in pilots, related to intensity and type of exposure may have an influence on BH and on HR (Kawada \& Suzuki 1999; Tomei et al. 1991; Tomei et al. 1992; Byers \& Smyth 1997; Talbott et al. 1999; Van Kempen et al. 2002).

The pilots of group A, who are at higher levels of exposure to noise, are at higher risk of $\mathrm{BH}$, in particular DBP, compared to group B.

In a group of workers, Talbott et al. (1999) assumed that chronic exposure to noise at levels $>89 \mathrm{~dB}(\mathrm{~A})$ was a significant predictor of $\mathrm{DBP}$.

The pilots in both groups could be exposed to other cardiovascular risk factors such as: vibration, acceleration, shifts, hypoxia and the variations of the microclimate (Van Kempen 2002). 
Some authors compared HR with BH (Burger et al. 1998) and atherosclerosis (Rehman et al. 1997). Studies showed that a resting $H R \geqslant 84$ beats $/ \mathrm{min}$, is predictive of an increase in cardiovascular mortality (Petiot et al. 1992). Tachycardia in hypertensives may reflect a sympathetic hyperactivity and a reduction in the vagal tone (Holand et al. 1999) and can be an additional indicator of cardiovascular risk. Many authors found that chronic exposure to noise provokes an increase in HR, probably due to a catecholamines response (Byers and Smyth 1997).

In the pilots of group A, ergometric tests confirm that exposure to higher levels of noise influence $\mathrm{BH}$, reducing response to workloads, probably due to lower sympathetic adaptability (Marciniak et al. 1999). In aeronautical workers exposed to noise at levels of $>90 \mathrm{~dB}(\mathrm{~A})$ Marciniak et al. (1999) have found structural change in the heart.

The reaching of the workloads may also depend on whether the subjects show a drop in basal BP or not. The low increase in the HR at maximum load might in some cases depend on muscular training or could be a sign of poor dysregulation adaptability of the sympatho-vagal balance.

Even though the level of noise while cruising, markedly lower in jet planes than in turboprop planes, is obviously important, account could also be taken of peaks during takeoff and landing, which are usually more numerous in the former (jet pilots land and take off more often than turboprop pilots). In jet planes the peaks are also related to the opening of the canopy during taxiing.

Studies on the relationship between hearing impairment and hypertension indicate that the response of the cardiovascular system is different from that of the hearing system (Merluzzi et al. 1987; Van Kempen et al. 2002).

The results on the relationships between $\mathrm{BH}$ and audiometric deficits seem to indicate that the vascular damage is accompanied by hearing impairment. The behavior observed is not similar for the ECG anomalies, indicating a less close relationship between these parameters and hearing impairment. In previous studies, it has been suggested that noise, depending on the intensity, duration and type of exposure and individual sensitivity, causes effects with different thresholds both for the system affected (cardiovascular and/or auditory) and the occurrence of the damage (type and extent): audiometric deficits and/or BH (Tomei et al. 1992; Van Kempen et al. 2002). Lastly, considering that the noise is mainly distributed over low frequencies, it could be suggested that studies should be done to confirm whether noise at low frequencies can have greater and more specific hypertensive effects (Tomei et al. 1992).

Noise reduction by means of flight helmets and headphones, already moderate at low frequencies, is further reduced by intercommunication systems. The effectiveness of such personal means of protection in satisfactorily attenuating noise, especially at low frequencies, is therefore not certain.

The results described agree with previous studies (Tomei et al. 1992; Van Kempen et al. 2002); drop in BP is a sign of a more sensitive cardiovascular effect than BH and ECG anomalies.

In this study, age is significantly different for pilots with $>3000$ flying hours for both types of pilots. Therefore, age and flying co-vary in the data. However, in pilots a greater number of flight hours, with consequent longer time of exposure to noise, cause greater prevalence of postural alterations in the BP. It may be suggested that the drop in BP might be related to an alteration of the baroreceptor sensitivity (Chester \& Barnett 1995) by chronic sympathetic activation with consequent dysregulation of the sympatho-vagal balance.

Chronic exposure to noise on the cardiovascular system may cause a high catecholamine secretion, with consequent catecholamine depletion and/or reduced catecholamine response, also due to $\beta$-receptor desensitization (Chester \& Barnett 1995). Then, a reduction in myocardial adrenergic $\beta$-receptors is associated with reduced cardiac response to the 
catecholamines (Fowler et al. 1986). Initially, the mechanism serves to protect against arrhythmias and toxic effects on the myocardium. In this study, the response of the sympathetic hypertonus to postural alterations, could be assumed to be precociously altered and the response of sympathetic hypertonus to workloads, is lower in the pilots of group A.

\section{Conclusions}

The different effects on the cardiovascular system might therefore depend on whether the clinical or experimental investigation is done (soon after the noise has started, after some length of exposure, or after a long exposure) and on related dysregulation of the sympathetic nervous system. In this research, pilots who had been exposed to noise for a long time were studied, so the effect might reflect catecholamine depletion and altered baroreceptor reflexes, probably no longer reversible.

\section{References}

Bao G, Metreveli N, Fletcher EC. 1999. Acute and chronic blood pressure response to recurrent acoustic arousal in rats. Am J Hypert 12:504-510.

Burger AJ, Homer AW, Larry A, Veinruch A, D'Elia S. 1998. Relation of heart rate variability and serum lipoprotein in type 1 diabetes mellitus and chronic stable angina. Am J Cardiol 81:945-949.

Byers JF, Smyth KA. 1997. Effect of a music intervention on noise annoyance, heart rate, and blood pressure in cardiac surgery patients. Am J Crit Care 6:183-191.

Chester MR, Barnett DB. 1995. Cardiac chamber-specific 3 -adrenoceptor regulation and sympathetic innervation. Lancet 345:553-555.

Fowler MB, Laser JA, Hopkins GL, Minobe W, Bristow MR. 1986. Assessment of the $\beta$-adrenergic receptor pathway in the intact failing human heart: Progressive receptor down-regulation and subsensitivity to agonist response. Circulation 74:1290-1302.

Holand S, Girard A, Laude D, Meyer-Bisch C, Elghozi JL. 1999. Effects of an auditory startle stimulus on blood pressure and heart rate in humans. J Hypertens 17:1893-1897.

Kawada T, Suzuki S. 1999. Change in rapid eye movement (REM) sleep in response to exposure to all-night noise and transient noise. Arch Environ Health 54:336-340.

Marciniak W, Rodriguez E, Olszowska K, Atkov O, Botvin I, Araujo A, Pais F, Soares Ribeiro C, Bordalo A, Loureiro J, Prazeres De Sa E, Ferreira D, Castelo Branco MS, Castelo Branco NA. 1999. Echocardiographic evaluation in 485 aeronautical workers exposed to different nois environments. Aviat Space Envir Med 70:46-53.

Merluzzi F, Dighera R, Duca P, Orsini S, Poletti R, Gori E, Laffi G, Viappiani F, Braga M. 1987. Hearing threshold of workers not exposed to occupational noise. Reference values. Med Lav 78:427-440.

Petiot JC, Parrot J, Lobreau JP, Smolik HJ. 1992. Cardiovascular effects of impulse noise, road traffic noise, and intermittent pink noise at $\mathrm{LAeq}=75 \mathrm{~dB}$, as a function of sex, age, and level of anxiety: A comparative study. II Digital pulse level and blood pressure data. Int Arch Occup Environ Health 63:485-493.

Rehman A, Zalos G, Andrews NP, Mulcahi D, Quyyumi AA. 1997. Blood pressure changes during transient myocardial ischemia: Insight into mechanism. J Am Coll Cardiol 30:1249-1255.

Sokas RK, Moussa MA, Gomes J, Anderson JA, Achuthan KK, Thain AB, Abu Risheh Z. 1995. Noise induced hearing loss, nationality, and blood pressure. Am J Ind Med 28:281-288.

Talbott EO, Gibson LB, Burks A, Engberg R, McHugh KP. 1999. Evidence for a dose-response relationship between occupational noise and blood pressure. Arch Environ Health 54:71-78.

Tomei F, Fantini S, Tomao E, Baccolo TP, Rosati MV. 2000. Hypertension and chronic exposure to noise. Arch Environ Health 55:319-325.

Tomei F, Tomao E, Papaleo B, Baccolo TP, Alf' P. 1991. Study of some cardiovascular parameters after chronic exposure to noise. Int J Card 33:393-400.

Tomei F, Tomao E, Papaleo B, Baccolo TP, Alfi' P. 1992. Vascular effects of noise. Angiology 43:904-912.

Van Kempen EE, Kruize H, Boshuizen HC, Ameling CB, Staatsen BA, De Hollander AE. 2002. The association between noise exposure and blood pressure and ischemic heart disease: A meta-analysis. Environ Health Perspect 110:307-317.

World Health Organization WHO. 1999. International Society of Hypertension Guidelines for the Management of Hypertension. J Hypertension 17:151-183. 
Copyright of International Journal of Environmental Health Research is the property of Taylor \& Francis Ltd and its content may not be copied or emailed to multiple sites or posted to a listserv without the copyright holder's express written permission. However, users may print, download, or email articles for individual use. 